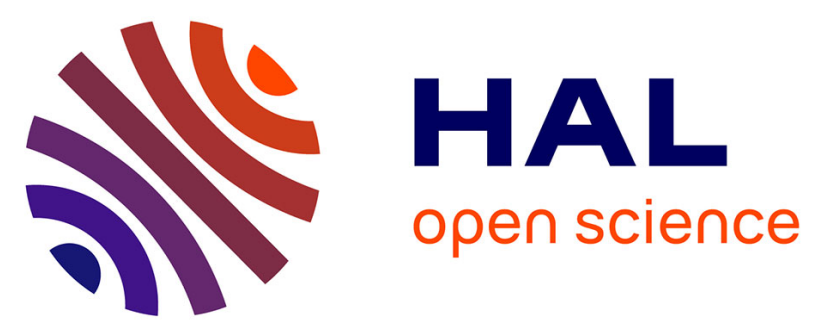

\title{
A review of the socioecological causes and consequences of cyanobacterial blooms in Lake Victoria
}

Mark Olokotum, Veronica Mitroi, Marc Troussellier, Ronald Semyalo, Cecile Bernard, Bernard Montuelle, William Okello, Catherine Quiblier, Jean-François Humbert

\section{To cite this version:}

Mark Olokotum, Veronica Mitroi, Marc Troussellier, Ronald Semyalo, Cecile Bernard, et al.. A review of the socioecological causes and consequences of cyanobacterial blooms in Lake Victoria. Harmful Algae, 2020, 96, pp.101829. 10.1016/j.hal.2020.101829 . mnhn-02635416

\section{HAL Id: mnhn-02635416}

\section{https://hal-mnhn.archives-ouvertes.fr/mnhn-02635416}

Submitted on 24 Sep 2020

HAL is a multi-disciplinary open access archive for the deposit and dissemination of scientific research documents, whether they are published or not. The documents may come from teaching and research institutions in France or abroad, or from public or private research centers.
L'archive ouverte pluridisciplinaire HAL, est destinée au dépôt et à la diffusion de documents scientifiques de niveau recherche, publiés ou non, émanant des établissements d'enseignement et de recherche français ou étrangers, des laboratoires publics ou privés.

\section{(ㅇ)(1) $\$$}

Distributed under a Creative Commons Attribution - NonCommercial - NoDerivatives| 4.0 
1 A review of the socioecological causes and consequences of cyanobacterial 2 blooms in Lake Victoria

3

4 Mark Olokotum ${ }^{1,2}$, Veronica Mitroi ${ }^{3}$, Marc Troussellier ${ }^{4}$, Ronald Semyalo ${ }^{5}$, Cécile Bernard ${ }^{6}$,

5 Bernard Montuelle ${ }^{7}$, William Okello ${ }^{2}$, Catherine Quiblier ${ }^{6,8 \#}$, Jean-François Humbert ${ }^{3 \#}$

6 8

$9 \quad{ }^{3}$ INRAE-Institute of Ecology and Environmental Sciences of Paris (iEES), Sorbonne

10 University, Paris, France

$11{ }^{4}$ UMR MARBEC, CNRS-University of Montpellier-IRD-IFREMER, Place Eugène Bataillon,

12 Montpellier, France

$13{ }^{5}$ Department of Zoology, Entomology and Fisheries Sciences, Makerere University, Kampala,

14 Uganda

$15{ }^{6}$ UMR 7245 Molécules de Communication et Adaptations des Microorganismes (MCAM),

16 CNRS-MNHN, Muséum National d'Histoire Naturelle, Paris, France

17

22 \# Corresponding authors 


\section{Abstract}

Africa is experiencing high annual population growth in its major river basins. This growth has resulted in significant land use change and pollution pressure on the freshwater ecosystems. Among them, the Lake Victoria basin, with more than 42 million people, is a unique and vital resource that provides food and drinking water in East Africa. However, Lake Victoria (LV) experienced a progressive eutrophication and substantial changes in the fish community leading to recurrent proliferation of water hyacinth and cyanobacteria. Based on an extensive literature review, we show that cyanobacterial biomasses and microcystin concentrations are higher in the bays and gulfs (B\&Gs) than in the open lake (OL), with Microcystis and Dolichospermum as the dominant genera. These differences between the B\&Gs and the OL are due to differences in their hydrological conditions and in the origins, type and quantities of nutrients. Using data from the literature, in this paper we describe the multiple ways in which the human population growth in the LV watershed is connected to the increasing occurrence of cyanobacterial blooms in the OL and B\&Gs. We also described the already documented consequences of cyanobacterial blooms on food resources and fishing and on direct water use and water supply of local populations, with their potential consequences on the human health. Finally, we discuss the actions that have been taken for the protection of LV. Although many projects have been implemented in the 15 past years in order to improve the management of waste waters or to reduce deforestation and erosion, the huge challenge of the reduction of cyanobacterial blooms in LV by the control of eutrophication seems far from being achieved.

Keywords: Cyanobacteria; Lake Victoria; Eutrophication; East Africa; Potential toxicity; Socioecological analysis; Consequences of cyanobacterial blooms 


\section{Introduction}

Numerous studies have been conducted in the past 20 years with the goal of improving our knowledge of the causes and consequences of cyanobacterial blooms. Taranu et al. (2015) have shown that the increasing occurrence of cyanobacterial blooms is clearly associated with the increasing impact of human activities on freshwater ecosystems during the Anthropocene, and it is well established that the main cause of cyanobacterial blooms is the nutrient enrichment of phosphorus (P) and nitrogen (N) (O'Neil et al., 2012, Huisman et al., 2018). Recently, several papers also suggested that climate change might directly or indirectly promote cyanobacterial blooms (e.g., Moss et al., 2011; Paerl et al., 2016; Ho et al., 2019). Blooms are also well known to have multiple impacts on the ecological functioning of freshwater ecosystems (e.g., Paerl et al., 2016; Huisman et al., 2018, Escalas et al., 2019) and on the goods and services (G\&S) they provide (e.g., Dodds et al., 2009). Finally, many papers deal with the production of harmful toxins by cyanobacteria and the sanitary risks associated with them (e.g., Briand et al., 2003; Merel et al., 2013; Meriluoto et al., 2017).

Among these previous studies, few papers have focused on developing countries, with the exception of a few countries such as Brazil and China (Merel et al., 2013). In particular, the issue of cyanobacterial blooms has been poorly investigated on the African continent, as illustrated recently by Svircev et al. (2019). When looking in this review at the distribution of cyanotoxins worldwide, it appears that data on cyanotoxins are available only for 14 of the 54 African countries and for 76 ecosystems on the continent. Among these ecosystems, Lake Victoria (LV) is the most studied, probably because it is the second largest lake in the world and provides goods and services (G\&S) to millions of people (Downing et al., 2014; ElNoshokaty, 2017). Moreover, LV has experienced rapid water quality degradation that has led to eutrophication, which is considered a major threat to the ecological function of the lake (Hecky et al., 1994; Juma et al., 2014) as it results in the recurrent proliferations of aquatic weeds (e.g., water hyacinth) and cyanobacteria (Lung'ayia et al., 2000; Opande et al., 2004, 
Juma et al., 2014). The proliferation of water hyacinth has been more or less controlled since the end of the 1990s with biological, mechanical or physical strategies (Opande et al., 2004; Wanda et al., 2015), but cyanobacteria blooms persist in LV, particularly in the bays and gulfs (B\&Gs) (Haande et al., 2011; Sitoki et al., 2012; Mbonde et al., 2015).

The LV basin has one of the highest population densities in Africa, with several large cities located along the banks of the large bays and gulfs (B\&Gs) (e.g., Kampala in Uganda, Kisumu in Kenya, and Mwanza in Tanzania) (Figure 1). An understanding of the interplay of ecological and socioeconomic processes acting directly or indirectly on the lake is of primary interest. In this context, we address the state of knowledge on (i) the distribution of cyanobacterial blooms and cyanotoxins in LV; (ii) the social and environmental factors and processes potentially explaining the occurrence of cyanobacterial blooms, with a particular emphasis on changes that have occurred in its watershed during the last 50 years; (iii) the consequences of these blooms on the ecosystem G\&S provided by the lake and (iv) the management practices implemented with the goal of reducing nutrient loads and consequently the cyanobacterial blooms.

Figure 1. The Lake Victoria catchment area with major land use occupation. Land use data obtained from the ESA Climate Change Initiative - Land Cover project 2017, accessed June 2019.

\section{Study site: the Lake Victoria basin}

The LV catchment area has a surface area of $184,200 \mathrm{~km}^{2}$ and is shared between five countries (Burundi, Kenya, Rwanda, Tanzania and Uganda). As shown in Figure 1, the catchment is dominated by cropland and grassland, with major build-up areas (for example

Kampala, Kisumu, Musoma and Mwanza) located on the shorelines of the B\&Gs. LV is located 1,100 meters above sea level in East Africa and is the source of the White Nile. The 
102 lake is shared between the three countries of Kenya (6\%), Tanzania (51\%) and Uganda

103 (43\%). LV has a shoreline of 3,500 $\mathrm{km}$ with many B\&Gs and a $68,000 \mathrm{~km}^{2}$ surface area,

104 making it the world's second largest freshwater lake and the largest lake in the intertropical

105 area (Dobiesz et al., 2010). The maximum depth of the lake is $80 \mathrm{~m}$, the average depth is 40

$106 \mathrm{~m}$, and the residence time of the water is 23 years. As shown by Talling (1966), Lake Victoria

107 is monomictic, the overturn period occurring between May and August, while early thermal

108 stratification occurs between September and December and persistent thermal stratification

109 from January to April (Muggide et al. 2005).

110 Depending on the areas, the general climate of the Lake Victoria basin ranges from a

111 modified equatorial type characterized by heavy rainfall throughout the year to a semiarid

112 type characterized by intermittent drought periods. Overall, there are two rainfall periods

113 (long rains, March-May, and short rains, October-December) with variations ranging from

$114870-1,561 \mathrm{~mm}$ in Uganda and from 400-2,736 $\mathrm{mm}$ in Tanzania. (Kizza et al.,2009). Water

115 temperature recorded at the surface of the lake range from $23^{\circ} \mathrm{C}$ to $29^{\circ} \mathrm{C}$ throughout the year

116 (Muggide et al., 2005).

118 3. Historical and current status of cyanobacteria and cyanotoxins in Lake Victoria

119 3.1. Historical and current status of cyanobacterial blooms

120 Recent evolution of the LV phytoplankton community. As shown from paleolimnological

121 data by Verschuren et al. (2002), the phytoplankton production in LV has increased since the

122 1930s. Though there is insufficient nutrient data for this time period, it appears that the

123 phosphorus concentrations increased (from 1.1 to $2.9 \mu$ moles $\mathrm{L}^{-1}$ between the $1960 \mathrm{~s}$ and 124 1990s) and that eutrophication manifested towards the end of the 1980s (Hecky, 1993; Hecky

125 et al., 2010). The increasing nutrient content led to an increase in the phytoplanktonic

126 biomasses and shifts in the diatom community, from the dominance of Aulacoseira to the 
127 dominance of Nitzschia (Stager et al., 2009) and in the total phytoplankton community, from

128 the dominance of green algae (Chlorophyta) and large diatoms (Bacillariophyta) to the

129 dominance of cyanobacteria (Lehman and Branstrator, 1994; Ochumba and Kibaara, 1989;

130 Kling et al. 2001; Verschuren et al., 2002; Hecky et al., 2010). This dominance of

131 cyanobacteria in phytoplankton communities is now frequently found in the three countries

132 bordering the lake (Kenya, Tanzania and Uganda), particularly in the numerous B\&Gs

133 (Figure 2).

134

135 Figure 2. Cyanobacteria blooms in Uganda, Murchison Bay (A); Kenya, Nyanza Gulf (B);

136 Tanzania, Mwanza Gulf (C) (@) Photos: J.F. Humbert, INRAE)

Differences in the phytoplankton biomasses and community compositions of the B\&Gs

and the OL. As noted by Talling (1987), the physicochemical conditions and microbial communities of the open lake (OL) are quite different from those of the B\&Gs. In the B\&Gs, phytoplankton biomasses are often $>30 \mu \mathrm{g}$ Chl-a $\mathrm{L}^{-1}$, with cyanobacteria often comprising more than $60 \%$ of the total phytoplanktonic biomass and frequently comprising more than $80 \%$ (Table 1). The rest of the phytoplanktonic community is mainly composed of

144 Chlorophyta, Cryptophyta, Dinophyta and Euglenophyta (e.g., Haande et al., 2011; Sitoki et al., 2012).

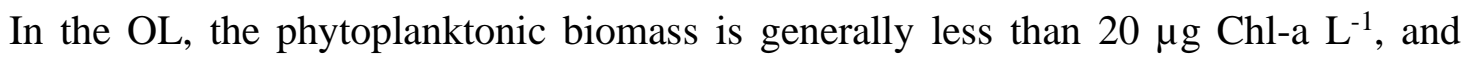

147 changes from a dominance of diatoms to a dominance of cyanobacteria are frequently found

148 (Table 1). The works of Lung'ayia et al. (2000) and Sitoki et al. (2012) in the Nyanza Gulf

149 and the OL in Kenya suggest that these changes could be partly driven by the alternation of 150 dry and rainy seasons. 
152

153

154

155

156

157

158

159

160

161

162

163

164

165

166

167

168

169

170

171

172

173

174

175

176

177

178

were clearly dominant in the OL during the dry season and represented $\leq 50 \%$ of the phytoplanktonic biomass during the rainy season. In the latter case, cyanobacteria were the second most dominant group of phytoplankton. Interestingly, Mbonde et al. (2015) have shown in a comparative study performed in 16 closed and open bays that the degree of connectivity of these bays to the OL greatly impacts their phytoplankton communities. The average phytoplankton biovolumes were much higher in the closed bays than in the open bays, and the same finding was found when considering only the cyanobacterial biovolumes (Supplemental Fig. 1).

Table 1. Overview of the published phytoplankton biomass (either as biovolume, cells $\mathrm{mL}^{-1}$, or chlorophyll-a estimates), the occurrence and abundance of cyanobacteria, the dominant species and the cyanotoxin microcystins in Lake Victoria. f.w.: fresh weight. w.w.: wet weight. MC: microcystins. Nd: not determined. NzG, Nyanza Gulf (Kenya), MB, Murchison Bay (Uganda); NG, Napoleon Gulf (Uganda); MG, Mwanza Gulf (Tanzania) (see the Supplemental Fig. 1 for the location of these sites )*Dolichospermum genus name is used instead of Anabaena.

Main cyanobacterial genera found in Lake Victoria. A great diversity of cyanobacterial taxa, including both nitrogen fixing taxa such as Dolichospermum, Cylindrospermopsis/Raphidiopsis or Anabaenopsis and nonnitrogen fixing taxa such as Microcystis, Planktolyngbya, Merismopedia, Cyanodictyon or Aphanocapsa, is often found in B\&Gs and the OL (Table 1). An underlying dominance of Dolichospermum spp. or Microcystis spp. cyanobacteria has been observed in the literature depending on the location, year and month of sampling considered. For example, Gikuma-Njuru et al. (2013a) observed a dominance of Dolichospermum and small cyanobacteria such as Cyanodictyon and Aphanocapsa between March 2005 and March 2006 in the Nyanza Gulf (Kenya), while Sitoki et al. (2012) found that Microcystis was clearly the most dominant cyanobacteria in the same 
179

180

181

182

183

184

185

area from July 2008 to September 2009. In Murchison Bay (Uganda), Microcystis dominance was noted by Poste et al. (2013), whereas the dominance of Dolichospermum was found in Murchison Bay and the Napoleon Gulf by Okello and Kurmayer (2011) and Okello et al. (2010a). Similar observations and alternations between a dominance of Dolichospermum and a very diversified cyanobacterial community were also observed by Haande et al. (2011), depending on the date and the sampling station within Murchison Bay. In Tanzania, Sekadende et al. (2005) found a dominance of diatoms and cyanobacteria belonging to the Planktolyngbya genus in the Mwanza Gulf between May and August 2002. Several years later, Mbonde et al. (2015) observed a dominance of Dolichospermum and Microcystis in the different B\&Gs of Tanzania, including the Mwanza Gulf, between November and December 2009.

There is no clear explanation for these spatial and temporal variations in the dominant cyanobacterial genera, but it is known that variations in nutrient concentrations can influence the composition of cyanobacterial communities. For example, it has been proposed that high proportions of N-fixing cyanobacteria such as Dolichospermum sp. could be linked to a nitrogen limitation in the lake (Mugidde et al., 2003; Gikuma-Njuru and Hecky, 2005). In the same way, many studies have shown that Microcystis sp. is the most common bloom-forming species in freshwater ecosystems with high phosphorus concentrations (e.g., Poste et al., 2013).

\subsection{Cyanotoxin production}

Microcystis and Dolichospermum genera are well known as the main potential producers of cyanotoxins of the microcystins (MC) family, but Dolichospermum is also known to produce several families of cyanotoxins including anatoxin-a (ATX) (Bernard et al., 2017). To our knowledge, all studies in LV have focused on MC, and only one study performed in the 
204 Nyanza Gulf (Kenya) focused on ATX (Kotut et al., 2006). Although Dolichospermum was 205 dominant and Microcystis was marginal, ATX was undetectable in both environmental 206 samples and in the isolated strains. During the same study period, the estimated MC 207 concentration was approximately $1 \mu \mathrm{g}$ eqMC-LR.L ${ }^{-1}$ (Krienitz et al., 2002; Kotut et al., 2006). 208 Some of these cyanobacteria are also known to potentially produce other cyanotoxins such as 209 the amino acid variant $\beta$-methyl-amino-L-alanine (BMAA) and saxitoxins, but these 210 cyanotoxins have not been investigated in LV. reporting the presence of MC was that of Krienitz et al. (2002) and was performed in the Nyanza Gulf (Table 1). After this first study, MC occurrence was recorded in different parts 214 of the lake, mainly in the B\&Gs but also in the OL in some cases (Sekadende et al., 2005; 215 Sitoki et al., 2012) (Table 1). Highly variable concentrations of MC were found in LV, from 216 less than $1 \mu \mathrm{g} . \mathrm{L}^{-1}$ in Murchison Bay (Uganda) (Semyalo et al., 2010) up to $81 \mu \mathrm{g} . \mathrm{L}^{-1}$ and $>2$ 217 mg. $\mathrm{L}^{-1}$ in Nyanza Gulf (Kenya) (Sitoki et al., 2012; Simiyu et al. 2018, respectively), the 218 highest concentrations being found in scums or at the surface of the lake (Table 1). A positive 219 correlation between the MC concentrations and Microcystis abundance was found by Okello 220 et al. (2010a, b), Sitoki et al. (2012) and Mbonde et al. (2015). Finally, Okello et al. (2010b) 221 observed during a one-year monitoring study (May 2007-April 2008) that the proportions of 222 the mcyB+ genotypes (potentially producing MC) in Microcystis populations varied from $3.3 \%$ to $39.2 \%$ in Murchison Bay and from $12.9 \%$ to $59.3 \%$ in the Napoleon Gulf.

So far, $240 \mathrm{MC}$ variants have been described in the world (Spoof and Catherine, 225 2017), but only a few studies have investigated the MC variant composition in the cyanobacterial blooms from LV (Table 1). Nevertheless, up to seven different variants have 227 been identified by Okello and Kurmayer (2011) and up to 31 variants have been identified by 228 Miles et al. (2013). However, the most common variants detected in the lake are MC-LR, 
MC-RR and MC-YR (e.g., Okello and Kurmayer, 2011, in Murchison Bay and the Napoleon

230 Gulf; Sitoki et al., 2012, in the Nyanza Gulf; Mbonde et al., 2015, in the Mwanza Gulf). The 231 proportions of all these MC variants were highly variable depending on the sampled area. For

232 example, the average estimated proportions of the MC-LR variant in the Murchison Bay and 233 the Napoleon Gulf (May 2007 - April 2008) were 12.4 $\pm 2 \%$ and $0.5 \pm 0.3 \%$, respectively, 234 according to Okello and Kurmayer (2011) but reached 50 $5 \%$ in the Nyanza Gulf (July 2008 235 - Sept 2009) (Sitoki et al., 2012). The small standard deviations associated with these 236 proportions seem to express low temporal variations for a given area in LV. However, higher 237 variations are sometimes reported in the literature, as shown for example by the large standard 238 deviation found in the mean proportion $(31 \pm 52 \%)$ of the MC-YR in the Nyanza Gulf (Sitoki 239 et al. 2012).

4. Linking demographic changes with the increasing occurrence of cyanobacterial 243 blooms

244 From the analysis of the data available in the literature on the causes of cyanobacterial blooms 245 in LV, we built a flow diagram (Figure 3) describing the multiple ways in which the human 246 population growth in the $\mathrm{LV}$ watershed is connected to the increasing occurrence of 247 cyanobacterial blooms in the OL and B\&Gs.

249 Figure 3. Links between the increase in the human population density around Lake Victoria 250 and the occurrence of cyanobacteria blooms in the open lake and in the bays and gulfs.

251 OM: Organic matter; P: Phosphorus; N: Nitrogen 
As summarized in Figure 3, the increase in the populations density in the LV basin, 254 such as everywhere in the world, has resulted in increasing food, housing and product demands (FAO, 2016). All these demands have many consequences on land use in the watershed, including farming and fishing activities, as well as formal and informal urbanization and industrial and commercial activities. All these processes are described in

section 4.1. Then, as developed in section 4.2, the changes occurring in anthropogenic activities and land use have led to increasing nutrient pollution in the OL and B\&Gs through three main processes: the aerial deposition of phosphorus and nitrogen, the discharge of mineral and organic nutrients by rivers and a decrease in natural purification due to wetland degradation. Finally, section 4.3 shows why the B\&Gs are more polluted than the OL and the processes leading to the decrease in water quality.

\subsection{Determinism and consequences of human population growth in the LV watershed}

Demographic data on the $\mathrm{LV}$ watershed. The African continent continues to experience a high annual population growth estimated at $2.6 \%$ per year in its major river basins (World Population Prospects, 2017). The population density in the LV basin almost doubled over the past 20 years from 27.2 million to ca. 42 million inhabitants (Bremer et al., 2013), which is considered the largest human population in the watersheds of the great lakes of the world (Dobiesz et al., 2010). This population increased by $2.4-3.2 \%$ annually (> $6 \%$ in some urban areas such as Kampala, Uganda; McDonald et al., 2014), a growth rate that is higher than that observed in the rest of the African continent (UNEP, 2006). The data from the Center for International Earth Science Information Network - CIESIN - Columbia University (2018) indicates that the population density in major cities has increased from a max of 100 persons per $\mathrm{km}^{2}$ to over 23,000 persons per $\mathrm{km}^{2}$ in the last two decades. A strong and similar exponential population increase has been observed since the 1960s in Kenya, Tanzania and 
278 Uganda (Supplemental Figure 2). On the other hand, Burundi and Rwanda, which 279 experienced civil war in the 1990s and do not have direct access to the lake, have seen much 280 lower population growth.

Causes of this population growth in the $\mathrm{LV}$ watershed. A recent report of the International

283 Institute for Sustainable Development (Dazé and Crawford, 2016) pointed out that migration 284 in the Great Lakes Region in East Africa is due partly to both voluntary decisions to migrate 285 and forced migration.

Concerning the voluntary migration, many people have migrated towards the lake basin to take advantage of the economic benefits linked to the fisheries in the basin (Awange and Obiero, 2006; Odada et al., 2009). As reported in Mkumbo \& Marshall (2015), more than $1,200,000$ people are directly or indirectly employed in fisheries, and income from fisheries supports approximately 4 million people. This makes LV the world's largest host for inland freshwater fisheries (Simonit and Perrings, 2011).

On the other hand, forced migrations have resulted from armed conflicts and violence in Rwanda and Burundi (from 1993 to 2005) and in the Democratic Republic of Congo (from 1996 to 2002). Many of these migrants are located in rural areas (Dazé and Crawford, 2016).

Consequences of population growth on land use, urbanization and anthropogenic activities. As established in the diagnostic analysis performed by the Lake Victoria 298 Environmental Management Project (LVEMP), more than $87 \%$ of the inhabitants living in the 299 LV basin are from the rural populations in Burundi, Kenya, Rwanda and Tanzania (see also 300 Figure 1), while in Uganda, 94\% of the inhabitants living in the LV basin are urban (LVEMP, 301 2007). Meanwhile, as already observed in the developing world (Montgomery, 2008), the 302 three countries with direct access to the lake and with livelihoods that rely on the lake have 
also experienced rapid urbanization that has led to the development of large cities located on the B\&Gs, such as Kampala (>2 million inhabitants) on Murchison Bay (Uganda), Kisumu (approximately 1 million inhabitants) on the Nyanza Gulf (Kenya) and Mwanza (>400,000 inhabitants) on the Mwanza Gulf (Tanzania) (Supplemental Fig 3).

The main consequence of increasing population densities in rural areas is a change in land use, particularly to cropland (see Figure 1). The agricultural development involves ca. > $80 \%$ inhabitants' that depend on small-scale mixed farming operations, thus, influencing the land use. As highlighted in the LVEMP report (LVEMP, 2007), agricultural development includes wetland destruction and/or degradation, livestock overgrazing, bush burning, land fragmentation, and deforestation. Deforestation (for settlement and agriculture development) is spreading at an alarming rate, e.g., in Uganda between 2000 and 2015, the deforestation rate was $3.3 \%$ annually, which is higher than that in other countries of the watershed $(0.2 \%$ for Burundi, $0.3 \%$ for Kenya, $1.7 \%$ for Rwanda and $0.8 \%$ for Tanzania) (FAO, 2015). This deforestation rate has increased from 1990-2015 in Uganda (from 2.0\% in 1990-2000 to 3.3\% in 2000-2010, reaching 5.5\% in 2010-2015). In typical developing countries, both rural and urban populations depend heavily on the forest environment and products, such as building materials, crafts, firewood, charcoal, food, flavoring, and traditional medicine, for their livelihood (UNEP, 2008; Mwavu \& Witkowski, 2008).

The drivers of deforestation identified in the LV watershed can be classified into two broad categories (Waiswa et al., 2015). The direct human uses of forest resources (Geist \& Lambin, 2002; Mwavu \& Witkowski, 2008) include the unplanned spread of agricultural areas over forest areas, firewood and timber harvesting, clearing forestland for human settlement, sand mining and brickmaking. The indirect drivers concern the underlying sociopolitical factors impacting human practices, such as unclear land tenure and/or property rights, lack of forest monitoring and the noninvolvement of users in forest maintenance, 
conflicts of interest, political interference, and negative perceptions about planning policies (Place \& Otsuka, 2000; Mwavu \& Witkowski, 2008).

\subsection{Relationships between land use changes and the eutrophication of $L V$}

As shown in Figure 3, various processes associated with land occupation changes and activities have led to the eutrophication of the OL and B\&Gs. Numerous studies have focused on identifying the different processes that lead to nitrogen and phosphorus pollution in LV, and four main processes have been identified. These processes include (i) the discharge of rivers from heavily polluted catchments (Verschuren et al., 2002; Musungu et al., 2014; Fuhrimann et al., 2015; Jovanelly et al., 2015); (ii) atmospheric deposition, in particular of phosphorus (P) (accounting for 55\% of the total phosphorus input in LV) (Tamatamah et al., 2005); (iii) the biological fixation of atmospheric dinitrogen $\left(\mathrm{N}_{2}\right)$, which seems to greatly exceed the contributions of atmospheric $\mathrm{N}$ deposition and river $\mathrm{N}$ inputs (Mugidde et al., 2003); and to a lesser extent, (iv) nutrient recycling and release from the sediments (GikumaNjuru et al., 2010).

The two first nutrient pollution pathways for LV water are directly linked to human population growth and activities. First, changes in land use patterns have contributed to enhanced erosion. In Uganda and Tanzania, the presence of settlements on the LV shoreline zone were associated with high soil erosion estimates of between 17 and 87 ton. $\mathrm{ha}^{-1} \cdot \mathrm{yr}^{-1}$ (Isabirye et al., 2010). The rate of soil loss in the LV basin also appears to depend on the land use system (tree plantation versus grassland) (Bamutaze et al., 2017). Other human-induced disturbances, such timber harvesting and soil compaction by cattle, also increase the risk of soil erosion (Karamage et al., 2017). Similarly, TP and TN atmospheric deposition mainly seem to result from burnt biomass, windblown dust and industrial and domestic activities (see the review of Cheruiyot and Muhandiki, 2014). 
Second, due to the urban human population growth, increasing quantities of solid and

354 liquid waste originate from (i) the human populations living in the large cities located near the

355 B\&Gs and (ii) industrial activities such as the activities of large manufacturers of steel

356 construction materials, factories that produce batteries, soap, paint, metal, plastics, corrugated

357 iron sheets, or pharmaceuticals, and breweries, tanneries, former copper smelters and abattoirs

358 (Muwanga and Barifaijo, 2006). Moreover, as shown by Cockx et al. (2019) in Tanzania, the

359 urbanization of the rural population results in changing food demands, which include

360 increasing consumption of high-sugar foods and drinks. These changes in the demand for

361 food have led for example to the installation of bottling factories in the three main cities

362 located around the lake (Kampala, Mwanza and Kisumu). For Kampala (Uganda), only ca.

$3638 \%$ of all wastes (domestic and industrial) are collected and treated (Matagi, 2002), and the

364 efficiency of the sewage treatment plants is poor, with up to ca. $89 \%$ frequency of

365 noncompliance with the national standard for BOD 5 (LVEMP, 2005). In the same way,

366 Oguttu et al. (2008) have shown that point source effluents due to increasing industrial

367 activities in the Jinja area have contributed to the increasing nutrient loads in the Napoleon

368 Gulf.

Finally, the progressive reduction and degradation of wetlands has played a major role

370 in the degradation of water quality. This degradation is due to housing, industrialization,

371 infrastructure development and agriculture (Kansiime \& Nalubega, 1999; Fuhrimann et al.,

372 2015). In the Kampala Metropolitan Area (Uganda), the proportion of severely degraded

373 wetlands increased from 13\% in 1993 to $46 \%$ by 1999 (Nyakaana et al., 2007). In particular,

374 Nakivubo wetlands experienced a 62\% loss in wetland vegetation between 2002 and 2014,

375 mainly due to crop cultivation (Isunju, 2016), despite their high estimated economic value of

376 between US\$ 760,000-1,300,000 (Schuijt, 2002). Similar observations have been made for the

377 Nyanza Gulf in Kenya by Juma et al. (2014). In Tanzania, Musamba et al. (2011), showed 
that an increase in the anthropogenic activities in the Musoma urban area was associated with

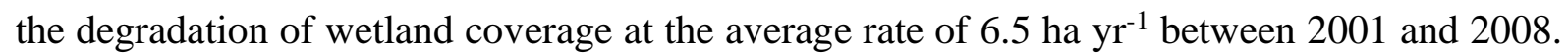
Knowing that wetlands are located at the mouths of the major rivers and in the inshore areas of the lake (Okeyo-Owuor et al., 2012) and that they play a major role in waste removal and water purification (Raburu et al., 2012), their degradation contributes to the decrease in water quality in the B\&Gs.

The consequences of all these processes acting on the nutrient load in Lake Victoria is that high concentrations in soluble elements ( $\mathrm{SRP}, \mathrm{NO}_{3}$ and $\mathrm{NH}_{4}$ ) have been recorded in the twenty past years in the Lake Victoria (Supplemental Table 1). The average TN:TP ratios are almost double in B\&Gs (14.5) than in OL (8.1) (Muggide et al., 2005). This suggests that there is a global $\mathrm{N}$ limitation in Lake Victoria, which is more pronounced in offshore area.

\subsection{Why do the bays and gulfs of LV have more cyanobacteria blooms than the open lake?}

Two main kinds of processes seem to be involved in the greater amount of eutrophication observed in the B\&Gs compared to the OL.

First, several big towns are located on the banks of the B\&Gs, such as Kampala on the Murchison Bay, Kisumu on the Nyanza Gulf and Mwanza on the Mwanza Gulf. As shown by Akurut et al. (2017) for the Murchison Bay (Uganda), the exponential deterioration of the water quality between 2001 and 2014 was largely due to increasing quantities of waste generated in Kampala City and discharged in the bay. Similar observations were made by Cornelissen et al. (2014) for the Mwanza Gulf (Tanzania). Several B\&Gs also receive water from rivers carrying high nutrient loads resulting from agricultural farmland in the catchment. This contribution has been shown for example for the Nyanza Gulf (Kenya) by Gikuma-Njuru et al. (2013b). As already described in paragraph 3.2, the decrease in the natural depuration in the wetlands located in the B\&Gs contributes to their hyper eutrophication. 
Second, the hydrodynamic conditions experienced by the B\&Gs favors cyanobacteria

404 blooms. In the closed B\&Gs (e.g., Murchison Bay, the Nyanza and Mwanza Gulfs) experiencing limited exchange with the OL, the water residence time is long, and the high nutrient load from their watersheds promote and sustain the development of cyanobacterial (1993) emphasized the importance of endemic phytoplanktivorous and detritivorous blooms. Moreover, the majority of the B\&Gs are very shallow, as illustrated by the Nyanza Gulf, which has a mean depth of $<10 \mathrm{~m}(<5 \mathrm{~m}$ in the eastern part of the gulf). Typically, at shallow depths, all water is mixed daily and there is thermal stratification during high insolation periods (Gikuma-Njuru, 2008). Consequently, the alternation of mixing and stratified periods can potentially promote the release of nutrients from the sediments, which can then sustain cyanobacteria growth (see for ex. Cao et al., 2016). In addition to the mixing and stratification that occurs at shallow water depths, the high turbidity occurring in these shallow and mixed B\&Gs (Silsbe et al., 2006; Loiselle et al., 2008 \& 2010) could promote the development of bloom-forming cyanobacteria such as Microcystis spp. or Dolichospermum spp., which are able to occupy the top of the water column where light is available for their growth, due to their gas vesicles (Gikuma-Njuru, 2008; Ssebiyonga et al., 2013).

\subsection{Other processes involved in the increasing occurrence of cyanobacterial blooms in LV}

Role of changes in the fish community. Nile perch and several tilapiine species (Nile tilapia:

Oreochromis niloticus L.; O. leucostictus; Tilapia zillii) were introduced into the lake in the 1950s and became dominant (Ogutu-Ohwayo, 2004; Awange and Obiero, 2006). Consequently, Marshall (2018) discussed the possibility that the changes in the fish community composition during the 1960s could have aggravated the symptoms of eutrophication and the proliferations of cyanobacteria in the lake. Although Goldschmidt et al. haplochromine species in the littoral and sublittoral areas of LV before the 1980s, these 
species were victims of Nile perch predation, that led to a dramatic decrease in their biomasses (Marshall, 2018). Thus, in the context of eutrophication, Batjakas et al. (1997) suggested that the replacement of endemic phytoplanktivorous species by predatory Nile perch could have facilitated the proliferation of cyanobacterial blooms. Moreover, as suggested by Marshall (2018), cyanobacteria could have been favored by the decrease in the population of large phytoplankton grazers from the zooplanktonic community due to their consumption by juvenile Nile perch. The other main introduced fish species (Nile tilapia, Oreochromis niloticus) is well-known to ingest a diversity of prey items including phytoplankton (e.g. Bwanika et al. 2006). In LV, many authors have reported that the diet of O. niloticus often have large proportion of phytoplankton dominated by cyanobacterial species (Semyalo et al, 2011, Rumisha \& Nehemia, 2013, Jihulya, 2014). Cyanobacteria has also been shown to contribute to the bulk of the diet of $O$. niloticus in other tropical aquatic ecosystems (Teferi et al. 2000, Turker et al. 2003, Lu et al. 2006, Torres et al. 2016, Zakaria et al. 2019). However, new data on the quantitative predation of cyanobacteria by $O$. niloticus are needed before concluding that this species may play a significant top-down role on the dynamics of cyanobacteria.

Since 2005, the stock of Nile perch in LV has rapidly decreased by approximately 50\%, mainly due to overfishing (Matsuishi et al. 2006, Mkumbo et al. 2007; Mkumbo and Marshall, 2015) but also because of the degradation of the water quality (e.g. anoxia). During the same period, the biomasses of other species such as Nile tilapia, catfishes or Protopterus biomasses have increased because they are less susceptible to degraded water quality (Kolding et al., 2008). The recent decrease in Nile perch stocks also favored an increase in haplochromine prey species, although their biomass and diversity remains low compared to the pre Nile perch era (Marshall, 2018). It is difficult to predict the consequences for cyanobacterial blooms to all these changes occurring in fish communities of LV knowing that 
453 the grazing rates of both fish and zooplankton always have always been low in Lake Victoria, 454 particularly since the 1980's (Witte et al., 2012).

455 In addition to the changes occurring in capture fisheries, the recent increases in cage 456 culture farms in the B\&Gs (Aura et al., 2018; Opiyo et al., 2018; Musinguzi et al., 2019) 457 constitutes an additional threat for the lake. It is well known that aquaculture can contribute 458 significantly to the nutrient enrichment of freshwater ecosystems (Zhang et al., 2006). In 459 Napoleon Gulf (Uganda), Egessa et al. (2018) observed organic matter and nutrient 460 enrichment in the sediment due to cage fish farming. In Shirati Bay (Tanzania), an increase in 461 nutrient concentrations was observed after cage farming establishment (Kashindye et al. 462 2015), while in Kenya, Njiru et al, (2018) reported increasing eutrophication in shallow areas 463 due to aquaculture waste feeds. These areas are only small portions of LV where caged fish 464 farming has occurred, but farming has begun to spread among the various B\&Gs of the lake. 465 Thus, additional data are needed to study this issue and its related consequences on water 466 quality.

468 Potential impact of climate change. The potential impact of climate change on 469 eutrophication in LV and consequently on cyanobacterial blooms has been poorly 470 investigated. Lehman et al. (1998) suggested that the eutrophication of LV may have been 471 accelerated by climate change, particularly by increased water temperature and reduced 472 vertical mixing, which are two processes that are known to influence the population dynamics 473 of cyanobacteria.

474 Recently, Tariku and Gan (2018), modeled the impacts of climate change on the 475 extreme precipitation indices and temperature of the River Nile Basin and indicated that the 476 extreme precipitation indices are projected to increase in the second part of this century. 477 Similarly, Thiery et al. (2016) projected that LV will be a hotspot for heavy thunderstorm 
478

479

480

481

482

483

484

485

486

487

488

489

490

491

492

493

494

495

496

497

498

499

500

501

502

events in a future with warmer climate scenarios. These changes might have dramatic consequences on LV because extreme rain events contribute to runoff and soil erosion, which enhance the eutrophication of aquatic ecosystems (e.g., Moss et al., 2011) and consequently the occurrence and intensity of cyanobacterial blooms (e.g., Michalak et al., 2013).

\section{Consequences of cyanobacterial blooms on the different uses of the lake}

\subsection{Consequences on food resources and fishing}

Fishing is an important food resource for approximately 1.5 million people living on the lake shores as well as for the 42 million inhabitants in the watershed of LV. In this context, cyanobacterial blooms have two main impacts on the fish communities: (i) the changes in the environmental conditions of the fish due to the blooms, with potential negative impacts on the abundance and diversity of the LV fish community, and (ii) the accumulation of cyanotoxins in the fish and the associated risks for the human populations consuming those fish.

It has been shown in numerous water bodies worldwide (e.g., Padmavathi \& Veeraiah, 2009; Lehman et al., 2010) that severe cyanobacterial blooms impact fish populations, mainly through changes induced in environmental parameters such as dissolved oxygen concentrations. Indeed, severe anoxia is recorded at the bottom of deep lakes or throughout the water column in shallow lakes due to the high respiration activity of bacteria degrading organic matter produced by cyanobacteria. In LV, several studies have linked water quality degradation to eutrophication and the changes occurring in the fish communities. For instance, Kundu et al. (2017) reported significant differences in the fish community structure in the Nyanza Gulf, where severe cyanobacterial blooms are frequently observed, and just outside of the gulf where better water quality occurs. Furthermore, Kolding et al. (2008) examined the relationship between the deterioration of water quality and the decline of Nile perch in the lake. They hypothesized that the low oxygen concentrations at the bottom of the 
503 lake resulting from the degradation of phytoplanktonic organic matter may be the cause of the 504 decline in Nile perch. However, this hypothesis is still in debate, as discussed by Mkumbo \& 505 Marshall (2015).

506 The second impact of cyanobacterial blooms on fish communities is associated with 507 the potential accumulation of cyanotoxins in the fish and their subsequent potential 508 consequences on human health. Based on laboratory and field studies in several countries, it is 509 known that MC can accumulate in fish tissues (e.g., Jiang et al., 2012; Nchabeleng et al., 510 2014). In LV, three studies (Semyalo et al., 2010; Poste et al., 2011 and Simiyu et al., 2018) 511 have shown the accumulation of MC in several fish species. The extent of MC accumulation 512 displayed considerable variability (from 0.5 to $90 \mu \mathrm{g} \cdot \mathrm{kg}^{-1}$ wet weight) among the fish species.

513 For the highest toxin concentrations, the estimated daily exposure to MC could exceed the 514 tolerable daily intake (TDI) proposed by the WHO for chronic exposure from fish consumption (i.e., TDI of $0.04 \mu \mathrm{g}$ MC-LR per kg body weight per day) (Ibelins and Chorus, 2007), especially for Haplochromis spp. and Rastrineobola argentea (Silver fish), which are

517 consumed whole. With the growing cage aquaculture in the B\&Gs of LV and the incidence of 518 increasing nutrient loading from aquaculture, cultured fish could accumulate cyanotoxins, but 519 no data are available. Consequently, all these data suggest that the consumption of fish from 520 LV could significantly contribute to the chronic exposure of human populations to MCs.

\subsection{Consequences of direct water use and water supply}

523 As shown in Table 1, the MC concentrations in the LV water frequently exceed $1 \mu \mathrm{g} . \mathrm{L}^{-1}$, 524 which is the threshold proposed by the WHO (Chorus and Bartram, 1999) for drinking water, 525 and sometimes exceed $10 \mu \mathrm{g} \cdot \mathrm{L}^{-1}$, which is the lowest threshold set by the sanitary authorities 526 from the northern countries for recreational activities (Chorus et al., 2012). Consequently, as 527 emphasized by Kotut et al. (2006), these MC concentrations in the B\&Gs are now a real 
challenge for local water authorities. However, regular monitoring of the MC concentrations in the lake water and in the treated water produced by the plants located in the B\&Gs is not regularly performed. Moreover, there is no information on the sanitary risks for people directly using lake water for domestic activities, including cooking and washing, or for recreational activities during bloom events.

In addition to the potential threat of cyanobacterial blooms to human populations through the consumption of raw or treated water or contaminated fish, these blooms have direct and indirect consequences on the price and quantity of drinking water produced by the treatment plants. In Uganda, Oyoo (2015) showed that cyanobacterial blooms impacted the price of the water in different ways. First, a clarification stage was added to the oldest water treatment plant (Gaba I) to improve the water quality. Second, the dosage of aluminum sulfate used in the plants increased three times from 1993 to 2008 due to the increasing prevalence of cyanobacterial blooms, and prechlorination was introduced to enhance coagulation and settling (Olokotum, 2017). Third, the cyanobacteria blooms in Murchison Bay have forced the water supply authorities and institutions to establish a new water treatment plant outside of the bay at Katosi (Damba channel), which will incur additional costs due to the construction of a long pipeline to carry the treated drinking water to the Kampala metropolitan area.

In addition to the increasing costs of water treatment due to cyanobacterial blooms, Oyoo (2015) reported the impacts of cyanobacterial blooms on the availability of water to local populations. The increased frequency of backwashing to avoid clogging of the sand filters during water treatment at Gaba I \& II in Kampala decreases the runtime of the machinery, which consequently decreases the quantity of water produced by the plants for populations. The costs of production and the availability of treated water are very important in developing countries because when the price increases and/or the availability decreases, the local populations tend to use alternative water resources that are not safe for their health (Moe 
553

554

555

556

557

558

559

560

561

562

563

564

565

566

567

568

569

570

571

572

573

574

575

576

577

and Rheingans, 2006).

Finally, from all these data, Figure 4 shows the potential health impacts of cyanobacterial blooms for human populations living around LV. Concerning the health impacts of cyanotoxins, limited data demonstrates their real adverse effects on human populations. However, due to the high recorded MC concentrations and the potentially high exposure of humans to these toxins (in comparison to populations from developed countries), these impacts on human health should be seriously considered. This hypothesis is supported by the recent paper of Roegner et al. (2020) showing that the health of peri-urban fisher communities in the area of Kisumu is threatened by the consumption and use of lake water contaminated with MCs and other HAB components. Moreover, in addition to the disturbances caused by cyanobacteria during the production of drinking water, human populations can also consume nontreated water from the lake or poorly treated water with potential exposure to fecal pathogens associated with waterborne diseases.

Figure 4. Potential impacts of cyanobacterial blooms on human health in Lake Victoria LW: Lake water; DW: Drinking water

\section{Efforts to reduce eutrophication and the occurrence/intensity of cyanobacterial} blooms

Knowing that it is well established that the eutrophication of freshwater ecosystems promotes cyanobacterial blooms, the reduction of external nutrient inputs in the lakes is the main sustainable strategy to reduce cyanobacterial blooms (e.g. Huisman et al., 2018). LV is a very complex socioecological ecosystem, and there is limited documented knowledge (and understanding) regarding the social and ecological dynamics and interactions involving LV. However, based on existing knowledge, we provide arguments for the eutrophication 
578 trajectory of LV and the necessity to carry out ambitious and sustainable management 579 measures to address this major problem. The modeling approach developed by Downing et al. 580 (2014) shows that controlling eutrophication is key to the protection and restoration of LV 581 and its ecosystem functions and G\&S. This finding is shared by many scientists as well as the 582 local and international authorities in charge of the management of LV. Over the past 10 years, 583 many actions have been taken to restore LV under the authorities of the East African 584 Community (EAC), Lake Victoria Fisheries Organization (LVFO), Lake Victoria 585 Environment Management Program (LVEMP), and Nile Basin Initiative (NBI) (Kayombo 586 and Jorgensen, 2006).

We have attempted to differentiate the issues affecting the B\&Gs and the OL resulting 588 from population growth and human activity because (i) the B\&Gs are more polluted than the 589 OL and (ii) the main sources of pollutants affecting these areas are different. The pollution of 590 the B\&Gs is largely due to the discharge of (i) solid and liquid wastes/pollutants originating 591 from big cities located on their banks and (ii) sediments and nutrients from the intensive 592 agricultural farmland. Consequently, efficient wastewater collection and treatment of these 593 domestic and industrial pollutants are critical in reducing the hyper eutrophication of the 594 B\&Gs. In Murchison Bay (Uganda), most of the influxing nutrients are carried by the 595 Nakivubo channel (Fuhrimann et al., 2015), comprising mainly the rainwater and the 596 domestic and industrial wastewater of Kampala (Matagi, 2002; Kayima et al., 2008). With 597 this goal in mind, the Kampala Capital City Authority (KCCA) launched the Green Industry 598 Campaign in 2016 with the goal of improving wastewater treatment (KCCA, 2018). Recently, 599 the KCCA also piloted a new action plan to improve fecal sludge collection and transport 600 from household pit latrines, which are common in Kampala suburbs (KCCA, 2017). Finally, 601 the construction of a new wastewater treatment plant in Kampala (Bugolobi/Nakivubo sewage 602 plant) should increase the sewage treatment capacities of the National Water and Sewerage 
603 Corporation (NWSC), which oversees water sanitation in Uganda. Similar approaches have

604 also been implemented for Kisumu located near the Nyanza Gulf in Kenya and for Mwanza

605 located near the Mwanza Gulf in Tanzania in the framework of the Lake Victoria Water

606 Sanitation Projects (LVWATSAN), which were first launched in 2004 but still continue to 607 support actions for the improvement of solid and liquid waste management 608 (https://unhabitat.org/the-lake-victoria-water-and-sanitation-project/).

All these actions are very important for the protection of the B\&Gs of LV, but estimating their "real" impacts on the improvement of the water quality in the B\&Gs remains

611 difficult. Indeed, in urban areas, the wastewater collection networks are still limited, which 612 results in the treatment of a small proportion of sewage, and with the predicted increased 613 population growth rate ( $2-5 \%$ annually), sewerage production will increase. In addition to improving wastewater collection and treatment, the protection and restoration of the numerous wetlands that are associated with the B\&Gs is also important. As

616 discussed before, many wetlands have been degraded due to the pressures linked to 617 population growth. Consequently, several projects in the three riparian countries around LV 618 focused on the rehabilitation of natural wetlands and the construction of artificial wetlands. 619 These programs are aimed at securing and maintaining the hydrological and ecological 620 integrity of wetlands (MWE, 2018). This initiative requires active involvement and 621 participation of the local communities living in these areas, as shown in Kenya by Raburu et 622 al. (2012) and in Uganda by Wacker et al. (2016).

623 Concerning the OL, it has been shown that in addition to river discharge, aerial 624 depositions are the main source of nutrient inputs in the lake (e.g., Tamatamah et al., 2005; 625 Kayombo \& Jorgensen, 2006). Therefore, a reduction of these inputs would be associated 626 with an integrated approach for the protection of the catchment area, including better soil 627 cover management and improved land use patterns (Okungu \& Opango, 2005; Vuai et al., 
628 2013). To adequately protect the watershed, deforestation needs to be halted and forests need

629 to be restored; this constitutes a much greater challenge due to the complexity of the drivers

630 of this phenomenon (Masese et al., 2012; Waiswa et al., 2015). These authors also note the

631 absolute need to involve local communities in all these processes.

632 In the framework of the Lake Victoria Environmental Management Project phases I

633 and II (LVEMP I and II), several soil conservation and afforestation projects were

634 implemented to limit soil erosion and the aerial deposition of nutrients in the lake. The impact

635 of these projects on the water quality of the OL has not been estimated. However, considering

636 the size of the watershed and the increasing population density, soil conservation projects will

637 require considerable concerted efforts by the five countries before expecting "significant 638 changes" in the water quality of the main lake.

639 In interaction with LVEMP projects, national management plans have also been 640 implemented in the countries belonging to the LV watershed. In Kenya for example, a master 641 plan for the conservation and sustainable management of water catchment areas was proposed 642 in 2012 by the Ministry of Environment and Mineral Resources (MEMR, 2012). Sub 643 catchment management plans have been implemented, for example for the Awach Kano, 644 leading to reduced deforestation, water pollution, gully erosion, etc. (Nyanchaga and Openji, 645 2017). In Tanzania, similar catchment-based actions have been implemented for the 646 protection of LV in the framework of Integrated Water Resources Management and 647 Development (IWRMD) plans (Domasa, 2019).

\section{7. Conclusion}

650 Due to the demographic growth and the rising concentration of the population into urban 651 areas in Africa (United Nation, 2018), we may fear that in the next decades, eutrophication of 652 freshwater ecosystems and associated cyanobacterial blooms will continue to increase in LV 
653 and also in many other African lakes. Knowing that all these lakes provide numerous

654 ecosystem G\&S and are vital for the water and food supply, the high microcystin 655 concentrations recorded in water and fishes of LV and the data of Roegner et al. (2020) 656 suggest that cyanobacteria and their toxins constitute a serious health concern for local 657 populations. The same is probably true in many countries of the intertropical area in Africa. 658 Consequently, it is becoming urgent in Africa (i) to implement long term monitoring 659 programs of cyanobacteria and cyanotoxins in lentic freshwater ecosystems, (ii) to define 660 water policies and rules for cyanobacteria and cyanotoxins and to inform human populations 661 about sanitary risks and (iii) to take actions for reducing the exposure of human populations to 662 cyanotoxins knowing that among these actions, the provision of affordable and easily 663 available treated-water is an urgent priority.

664 In a longer-term perspective, the battle against eutrophication will be one of the great 665 challenge of African countries. As shown in this review, the three main axes in this battle will 666 concern (i) the wastewater treatment and management in urban areas knowing that currently 667 available treatment methods might not be used in Africa due for example, to the lack of 668 appropriate structure (Wang et al., 2014), (ii) the promotion of a sustainable agriculture, such 669 as conservation agriculture, allowing to provide foods to a growing population whilst 670 minimizing environmental impacts (Giller et al., 2015) (iii) the protection and restoration of 671 wetlands, which can play a very important role in nutrient retention and reduction, even for 672 great lakes (Watson et al., 2016) . As already experienced in developed countries, all these actions for reducing the 674 exposure of human populations to cyanotoxins and the eutrophication will be very costly and 675 consequently require international financial cooperation. There is also need for international 676 collaborative research programs involving scientists and people from local institutions 
677 working in the water domain. Finally, the involvement and participation of the local 678 communities will be also a key factor for their successful development.

679

680

681

682

683 


\section{Acknowledgement}

685 This review paper has been prepared in the framework of the WaSAf program, which is 686 funded by the French Facility for Global Environment (Fonds Français pour l'Environnement 687 Mondial, FFEM).

688

689

690

691 


\section{References}

Akurut, M., Niwagaba, C.B., Willems, P., 2017. Long-term variations of water quality in the Inner Murchison Bay, Lake Victoria. Environ. Monit. Assess 189(1), 22.

Aura, C. M., Musa, S., Yongo, E., Okechi, J. K., Njiru, J. M., Ogari, Z., Wanyama, R., CharoKarisa, H., Mbugua, H., Kidera, S., Ombwa V., Oucho, V., 2018. Integration of mapping and socio-economic status of cage culture: Towards balancing lake-use and culture fisheries in Lake Victoria, Kenya. Aquacult. Res. 49(1), 532-545.

Awange, J.L., Obiero, O., 2006. Lake Victoria-Ecology, Resources, Environment. Heidelberg. Springer Berlin.

Bamutaze, Y., Wanyama, J., Diekrugger, B., Meadows, M., Opedes H., 2017. Dynamics of surface runoff and soil loss from a toposequence under varied land use practices in Rwizi catchment, Lake Voctoria Basin. J. Soil Water Cons. 72, 480-492.

Batjakas, I.E., Edgar, R.K., Kaufman, L.S., 1997. Comparative feeding efficiency of indigenous and introduced phytoplanktivores from Lake Victoria: Experimental studies on Oreochromis esculentus and Oreochromis niloticus. Hydrobiologia 347, 7582.

Bernard, C, Ballot, A., Thomazeau, S., Maloufi, S., Furey, A., Mankiewicz-Boczek, J., Pawlik-Skowronska, B., Capelli, C., Salmaso, N., 2017. In book: Handbook of Cyanobacterial Monitoring and Cyanotoxin Analysis, Edition: 1st, Chapter: Cyanobacteria associated with the production of cyanotoxins, Publisher: Wiley, Editors: Jussi Meriluoto, Lisa Spoof, Geoffrey Codd, pp. 501 - 525.

Bremer, J., Lopez-Carr, D., Zvoleff, A., Pricope, N., 2013. Using new methods and data to assess and adress population, fertility, and environment links in the Lake Victoria. XXVII IUSSP International Population Conference. https://iussp.org/sites/default/files/event_call_for_papers/IUSSP_paper_JBremner_etal _0.pdf.

Briand, J.F., Jacquet, S., Bernard, C., Humbert, J.F., 2003. Health hazards for terrestrial vertebrates from toxic cyanobacteria in surface water ecosystems. Vet. Res. 34, 361377.

Bwanika, G.N., Chapman, L.J., Kizito, Y., Balirwa, J., 2006. Cascading effects of introduced Nile perch (Lates niloticus) on the foraging ecology of Nile tilapia (Oreochromis niloticus). Ecol. Freshw. Fish, 15, 470-481.

Cao, X., Wang, Y., He, J., Luo, X., Zheng, Z., 2016. Phosphorus mobility among sediments, water and cyanobacteria enhanced cyanobacteria blooms in eutrophic Lake Dianchi. Environmental Pollution 219, 580-587.

Cheruiyot, C. Muhandiki, V., 2014. Review of estimation of pollution load to Lake Victoria. J. Environ. Earth Sci. 4, 113-120.

Chorus, I., 2012. Current approaches to Cyanotoxin risk assessment, risk management and regulations in different countries. Edited by Section II Drinking Water and Swimming Pool Water Hygiene, Federal Environment Agency, Germany Eds, 151pp.

Chorus, I., Bartram, J., 1999. Toxic cyanobacteria in water : A guide to their public health consequences, monitoring and management. E\&FN Spon, London \& New York.

Center for International Earth Science Information Network - CIESIN - Columbia University, 2018. Gridded Population of the World, Version 4 (GPWv4): Population Density, Revision 11. Palisades, NY: NASA Socioeconomic Data and Applications Center (SEDAC). Retrieved from: https://doi.org/10.7927/H49C6VHW. Thursday 13th June 2019.

Cockx, L., Colen, L., De Weerdt, J., Gomez, Y., Paloma, S., 2019. Urbanization as a driver of changing food demand in Africa: Evicence from rural-urban migration in Tanzania. 
JCR Technical Reports, 51 p. (doi:10.2760/515064).

Cornelissen, I.J.M., Silsbe, G.M., Verreth, J.A.J., van Donk, E., Nagelkerke, L.A.J., 2014. Dynamics and limitations of phytoplankton biomass along a gradient in Mwanza Gulf, southern Lake Victoria (Tanzania). Fresh. Biol. 59, 127-141.

Dazé, A., Crawford, A., 2016. Human migration and ecosystems: Insights from the Grat Lakes Region of East and Central Africa. IISD Report, 20 p.

Dobiesz, N.E., Hecky, R.E., Johnson, T.B., Sarvala, J., Dettmers, J.M., Lehtiniemi, M., Rudstam, L.G., Madenjian, C.P., Witte, F., 2010. Metrics of ecosystem status for large aquatic systems - A global comparison. J. Great Lakes Res. 36(1), 123-138.

Dodds, W.K., Bouska, W.W., Eitzmann, J.L., Pilger, T.J., Pitts, K.L., Riley, A.J., Schloesser, J.T., Thornbrugh, D.J., 2009. Eutrophication of US freshwaters: Analysis of potential economic damages. Environ. Sci. Technol. 43(1), 12-19.

Domasa, S., 2019. How can we best protect Lake Victoria's ecosystem? The Niles. Retrieved from https://www.theniles.org/en/articles/politics/20625/

Downing, A.S., van Nes, E.H., Balirwa, J.S., Beuving, J., Bwathondi, P.O. J., Chapman, L.J., Cornelissen, L., Cowx, I.G., Goudswaard, K.P.C., Kecky, R.E., Janse, J.H., Janssenn, A.B.G., Kaufamn, L., Kishe-Machumu, M.A., Kolding, J., Ligtvoet, W., Mbabazi, D., Merdard, M., Mkumbo, Malponi, E., Munyaho, A.T., Nagelkerke, N.A.J., Ogutu-Ohwayo, R., Ojwang, W.O., Peter, H.K., Schindler, D.E., Seehausen, O., Sharpe, D., Silsbe, G.M., Sitoki, L., Tumwebase, R., Tweddle, D., van de Wolfshaar, K.E., van Dijk, H., van donk, E., van Rijssel, J.C., van Zwieten P.A.M., Wanink, J., Witte, F., Mooij, W.M., 2014. Coupled human and natural system dynamics as key to the sustainability of Lake Victoria's ecosystem services. Ecol. Soc. 19(4), 31. doi.org/10.5751/ES-06965-190431.

Egessa, R., Pabire, G.W., Ocaya, H., 2018. Benthic macroinvertebrate community structure in Napoleon Gulf, Lake Victoria: effects of cage aquaculture in eutrophic lake. Environ. Monitoring and Assessment, 190(3), 112.

El-Noshokaty, D., 2017. Big Lakes, Big Problems. Is There Still Time to Secure the Water Resources Lake Victoria Provides? International Reports of the Konrad-AdenauerStiftung. 11p.

Escalas, A., Catherine, A., Maloufi, S., Cellamare, M., Hamlaoui, S., Yéprémian, C., Louvard, C., Troussellier, M., Bernard, C., 2019. Drivers and ecological consequences of dominance in periurban phytoplankton communities using networks approaches. Wat. Res. 163, 114893.

Food and Agricultural Research Organisation-FAO, 2015. The state of food insecurity in the World. doi.org/http://www.fao.org/.

Food and Agricultural Research Organisation-FAO, 2016.Economic analysis of food supply and demand in sub-Saharan Africa up to 2022 - special focus on fish and fishery products, by Trond Bjørndal, Alena Lappo, Madan Dey, Audun Lem and Anna Child. Fisheries and Aquaculture Circular No. 1101. Rome, Italy.

Fuhrimann, S., Stalder, M., Winkler, M.S., Niwagaba, C.B., Babu, M., Masaba, G., Kabatereine, N.B., Halage, A.A., Schneeberger, P.H.H., Utzinger, J., Cissé, G., 2015. Microbial and chemical contamination of water, sediment and soil in the Nakivubo wetland area in Kampala, Uganda. Environ Monit. Assess. 187:475. DOI 10.1007/s10661-015-4689-x

Geist, H., Lambin, E., 2002. Proximate causes and underlying driving forces of tropical deforestation. Biosci. 52, 143-150.

Gikuma-Njuru, P., 2008. Physical and biogeochemical gradients and exchange processes in Nyanza gulf and main Lake Victoria (East Africa). PhD Thesis, University of Waterloo, Waterloo. 
Gikuma-Njuru, P., Hecky, R.E., 2005. Nutrient concentrations in Nyanza Gulf, Lake Victoria, Kenya: light limits algal demand and abundance. Hydrobiologia 534, 131-140.

Gikuma-Njuru, P., 2008. Physical and biogeochemical gradients and exchange processes in Nyanza Gulf and main Lake Victoria (East Africa). PhD Thesis. University of Waterloo, Ontario, Canada.

Gikuma-Njuru, P., Hecky, R.E., Guildford, S.J., 2010. Surficial sediment phosphorus fractions along a biogeochemical gradient in Nyanza (Winam) Gulf, northeastern Lake Victoria and their possible role in phosphorus recycling and internal loading. Biogeochem. 97, 247-261.

Gikuma-Njuru, P., Guildford, S.J., Hecky, R.E., Kling, H.J., 2013a. Strong spatial differentiation of $\mathrm{N}$ and $\mathrm{P}$ deficiency, primary productivity and community composition between Nyanza Gulf and Lake Victoria (Kenya, East Africa) and the implications for nutrient management. Freshw. Biol. 58(11), 2237-2252.

Gikuma-Njuru, P., Hecky, R.E., Guildford, S.J., Macintyre, S., 2013b. Spatial variability of nutrient concentrations, fluxes, and ecosystem metabolism in Nyanza Gulf and Rusinga Channel, Lake Uictoria (East Africa). Limnol. Oceanogr. 58(3), 774-789.

Giller, K.E., Andersson, J.A., Corbeels, M., Kirkegaard, J., Mortensen, D., Erenstein, O., Vanlauwe, B., 2015. Beyond conservation agriculture. Front. Plant Sci. 6, 870.

Goldschmidt, T., Witte, F., Wanink, J., 1993. Cascading Effects of the Introduced Nile Perch on the Detritivorous/Phytoplanktivorous Species in the Sublittoral Areas of Lake Victoria. Conserv. Biol. 7(3), 686-700.

Haande, S., Rohrlack, T., Semyalo, R. P., Brettum, P., Edvardsen, B., Lyche-Solheim, A., Sorensen, K., Larsson, P., 2011. Phytoplankton dynamics and cyanobacterial dominance in Murchison Bay of Lake Victoria (Uganda) in relation to environmental conditions. Limnologica - Ecology and Management of Inland Waters 41(1), 20-29.

Hecky, R.E., 1993. The eutrophication of Lake Victoria. Verhandlungen Des Internationalen Verein Limnol. 25, 39-48.

Hecky, R.E., Bugenyi, F.W.B., Ochumba, P., Talling, J.F., 1994. Deoxygenation of the deep water of Lake Victoria, East Africa. Limnol. Oceanogr. 39(6), 1476-1481.

Hecky, R.E., Muggide, R., Ramsal, P.S., Talbot, M.R., Kling, G.W., 2010. Multiple stressors cause rapid ecosystem change in Lake Victoria. Freshw. Biol. 55(Suppl. 1), 19-42.

Ho, J.C., Michalak, A.M., Pahlevan, N., 2019. Widespread global increase in intense lake phytoplankton blooms since the 1980s. Nature 574, 667

Huisman, J., Codd, G.A., Paerl, H.W., Ibelings, B.W., Verspagen, J.M.H., Visser, P.M., 2018. Cyanobacterial blooms. Nature Rev. Microbiol. 16(8). DOI: 10.1038/s41579-0180040-1.

Ibelings, B.W., Chorus, I., 2007. Accumulation of cyanobacterial toxins in freshwater "seafood" andits consequences for public health: A review. Environ. Pollut. 150, 177-192.

Isabirye, M., Kimaro, D., Semalulu, O., 2010. Sediment production from settlements and farmlands within Lake Victoria shoreline zone in Uganda and Tanzania. Tropicultura 28, 89-95.

Isunju, J.B., 2016. Spatiotemporal analysis of encroachment on wetlands: hazards, vulnerability and adaptations in kampala city, Uganda. PhD Dissertation. University of Stellenbosch, South Africa.

Jiang, J., Shi, Y., Shan, Z., Yang, L., Wang, X., Shi, L., 2012. Bioaccumulation, oxydative stress and HSP70 expression in Cyprinus carpio L. exposed to microcystin-LR under laboratory conditions. Comparative Biochemistry and Physiology Part C: Toxicol. Pharmacol. 155 (3), 483-490.

Jihulya, N.J. 2014. Diet and feeding ecology of Nile tilapia, Oreochromis niloticus and Nile 
perch, Lates niloticus in protected and unprotected areas of Lake Victoria, Tanzania. Int. J. Sci. Technol. Res. 3, 280-286.

Jovanelly,T. J., Johnson-Pynn, J., Okot-Okumu, J., Nyenje, R., Namaganda, E., 2015. Pioneering water quality data on the Lake Victoria watershed: Effects on human health. J. Wat. Health 13(3), 920-930.

Juma, D.W., Wang, H., Li F., 2014. Impacts of population growth and economic development on water quality of a lake: case study of Lake Victoria Kenya water. Environ. Sci. Poll. Res. 21, 5737-5746

Kabenge, M., Wang, H., Li, F., 2016. Urban eutrophication and its spurring conditions in the Murchison Bay of Lake Victoria. Environ. Sci. Pollut. Res. Int. 23, 234-241.

Kampala Capital City Authority-KCCA, 2017. Piloting a mobile sludge transfer tank in 5 parishes of Kampala. https://www.kcca.go.ug/news/242/Piloting-a-mobile-sludgetransfer-tank-in-5-parishes-of-Kampala\#.XCTz5W1RWM8

Kampala Capital City Authority-KCCA, 2018. What is the Kampala Green Industry Campaign. https://www.kcca.go.ug/ptf-gic

Kansiime, F., Nalubega, M., 1999. Wastewater Treatment by a Natural Wetland: The Nakivubo Swamp, Uganda. IHE. http://edepot.wur.nl/192727.

Karamage, F., Zhang, C., Liu, T. Maganda, A., Isabwe, A., 2017. Soil erosion risk assessment in Uganda. Forests 8, 52.

Kashindye, B. B., Nsinda, P., Kayanda, R., Ngupula, G. W., Mashafi, C. A., \& Ezekiel, C. N., 2015. Environmental impacts of cage culture in Lake Victoria: the case of Shirati BaySota, Tanzania. SpringerPlus, 4, 475-475. doi:10.1186/s40064-015-1241-y

Kayima, J., Kyakula, M., Komakech, W., Echimu, S.P., 2008. A study of the degree of pollution in Nakivubo Channel, Kampala, Uganda. J. Environ. Sci. Appl. Manag. 12(2), 93-98.

Kayombo, S., Jorgensen, S.E., 2006. Lake Victoria: Experience and Lessons Learned Brief, In: Lake Basin Management Initiative: Experience and Lessons Learned Briefs (on CD). International Lake Environment Committee Foundation, Kusatsu, Japan, pp. 431-446.

Kizza, M., Rodhe, A., Xu, C.Y., Ntale, H.K., Halldin, S., 2009. Temporal rainfall variability in the Lake Victoria Basin in East Africa during the twentieth century. Theor. Appl. Climatol. 98, 119-135.

Kling, H.J., Mugidde, R., Hecky, R.E., 2001. Recent changes in the phytoplankton community in response to eutrophication. In M. Munawar R.E. Hecky (Eds.), The Great Lakes of the World (GLOW): Food-web, health and integrity (pp. 44-65). Leiden, The Netherlands: Backhuys.

Kolding, J., van Zwieten, P., Mkumbo, O., Silsbe, G., Hecky, R.E., 2008. Are the Lake Victoria fisheries threatened by exploitation or eutrophication? Towards an ecosystem based approach to management. In R. Bianchi, \& H. R. Skjoldal (Eds.), The ecosystem approach to fisheries. (pp 309-354). Rome: CABI Publishing.

Kotut, K., Ballot, A., Krienitz, L., 2006. Toxic cyanobacteria and their toxins in standing waters of Kenya: implications for water resource use. J. Wat. Health 4(Suppl. 2), 3-18.

Krienitz, L., Ballot, A., Wiegand, C., Kotut, K., Codd, G.A., Pflugmacher, S., 2002. Cyanotoxin-producing bloom of Anabaena flos-aquae, Anabaena discoidea and Microcystis aeruginosa (Cyanobacteria) in Nyanza Gulf of Lake Victoria, Kenya. J. Appl. Bot. 76, 179-183.

Kundu, R., Aura, C.M., Nyamweya, C., Agembe, S., Sitoki, L., Lung'ayia, H., Ongore, C., Ogari, Z., Werimo, K., 2017. Changes in pollution indicators in Lake Victoria, Kenya and their implications for lake and catchment management. Lakes Reserv. Res. Manag. 22(3), 199-214. 
891

892

893

894

895

896

897

898

899

900

901

902

903

904

905

906

907

908

909

910

911

912

913

914

915

916

917

918

919

920

921

922

923

924

925

926

927

928

929

930

931

932

933

934

935

936

937

938

939

940

Lake Victoria Environmental Management Project (LVEMP), 2005. Water quality and ecosystem status. http://hdl.handle.net/11671/718

Lake Victoria Environmental Management Project (LVEMP), 2007. Preparation of National / Regional Management Framework: Institutional Component for the Lake Victoria Basin Final National Report. http://repository.eac.int.

Lehman, J.T., 1998. Role of climate in the modern condition of Lake Victoria. Theor. Appl. Climatol. 61, 29-37.

Lehman, J.T., Branstrator, D.K., 1994. Nutrient dynamics and turnover rates of phosphate and sulfate in Lake Victoria, East Africa. Limnol. Oceanogr. 39(2), 227-233.

Lehman, P.W., The, S.J., Boyer, G.L., Nobriga, M.L., Bass, E., Hogle, C., 2010. Initial impacts of Microcystis aeruginosa blooms on the aquatic food web in the San Francisco Estuary. Hydrobiologia 637, 229-248.

Loiselle, S.A., Azza, N., Cozar, A., Bracchini, L., Tognazzi, A., Dattilo, A., Rossi, C., 2008. Variability in factors causing light attenuation in Lake Victoria. Freshw. Biol. 53 (3), 535-545.

Loiselle, S.A., Azza, N., Gichuki, J., Bracchini, L., Tognazzi, A., Dattilo, A.M., Rossi, C., 2010. Spatial dynamics of chormophoric dissolved organic matter in nearshore waters of Lake Victoria. Aquat. Ecosyst. Health Manag. 13, 1-11.

Lu, K., Jin, C., Dong, S., Gu, B., Bowen, S.H., 2006. Feeding and control of blue-green algal blooms by tilapia (Oreochromis niloticus). Hydrobiologia, 568, 111-120.

Lung'ayia, H.B.O., M'harzi, A., Tackx, M., Gichuki, J., Symoens, J.J., 2000. Phyotplankton community structure and environment in the Kenyan waters of Lake Victoria. Freshw. Biol. 43, 529-543.

Marshall, B.E., 2018. Guilty as charged: Nile perch was the cause of the haplochromine decline in Lake Victoria. Can. J. Fish. Aquat. Sci. 75(9), 1542-1559.

Masese, F.O., Raburu, P.O., Mwasi, B.N., Etiégni, L., 2012. Effects of Deforestation on Water Resources: Integrating Science and Community Perspectives in the SonduMiriu River Basin, Kenya. IntechOpen: New Advances and Contributions to Forestry Research, 3-18. doi.org/10.5772/2246.

Matagi, S.V., 2002. Some Issues of Environmental Concern in Kampala, the Capital City of Uganda. Environ. Monit. Assess. 77, 121-138.

Matsuishi, T., Muhoozi, L., Mkumbo, O., Budeba, Y., Njiru, M., Asila, A., Othina, A., Cowx I.G., 2006. Are the exploitation pressures on the Nile perch fisheries resources of Lake Victoria a cause for concern? Fish. Manag. Ecol. 13(1), 53-71.

Mbonde, A.S., Sitoki, L., Kurmayer, R., 2015. Phytoplankton composition and microcystin concentrations in open and closed bays of Lake Victoria, Tanzania. Aquat. Ecosyst. Health Manag. 18(2), 212-220.

MEMR, 2012. Masterplan for the conservation and sustainable management of water catchment areas in Kenya. Ministry of Environment and Mineral Resources (https://www.preventionweb.net/files/34692_conservationmasterplanfinal.pdf).

Merel, S., Walker, D.B., Chicana, R., Synder, S.A., Baures, E., Thomas, O., 2013. State of knowledge and concerns on cyanobacterial blooms and cyanotoxins. Environ. Internat. 59, 303-327.

Meriluoto, J., Blaha, L., Bojadzija, G., Bormans, M., Brient, L., Codd, G. A., Drobac, D., Faassen, E.J., Fastner, J., Hiskia, A., Ibelings, B.W., Kaloudis, T., Kokocinsky, M., Kurmayer, R., Pantelic, D., Quesada, A., Salmaso, N., Tokodi, N., Triants, T.M., Visser, P.M., Svirčev, Z., 2017. Toxic cyanobacteria and cyanotoxins in European waters - recent progress achieved through the CYANOCOST Action and challenges for further research. Adv. Oceanogr. Limnol. 8(1), 161-178.

Michalak, A. M., Anderson, E.J., Beletsky, D., Boland, S., Bosch, N.S., Bridgeman, T.B., 
Chaffin, J.D., Cho, K., Confesor, R., Daqloglu, I., DePinto, J.V., Evans, M.A., Fahnenstiel, G.L., He, L., Ho, J.C., Jenkins, L., Johengen, T.H., Kuo, K.C., LaPorte, E., Liu, X., McWilliams, M.R., Moore, M.M., Posselt, D.J., Richards, R.P., Scavia, D., Steiner, A.L., Verhamme, E., Wirght, D.M., Zagorski, M.A., 2013. Record-setting algal bloom in Lake Erie caused by agricultural and meteorological trends consistent with expected future conditions. Proc. Nat. Acad. Sci. USA 110(16), 6448-6452.

Miles, C.O., Sandvik, M., Nonga, H.E., Rundberget, T., Wilkins, A.L., Rise, F., Ballot, A., 2013. Identification of microcystins in a Lake Victoria cyanobacterial bloom using LC-MS with thiol derivatization. Toxicon 70, 21-31.

Ministry of Water and Environment-MWE, 2018. Wetlands Management Department. https://www.mwe.go.ug/dept/wetlands-management-department.

Mkumbo, O.C., Marshall, B.E., 2015. The Nile perch fishery of Lake Victoria: Current status and management challenges. Fish. Manag. Ecol. 22(1), 56-63.

Mkumbo, O.C., Nsinda, P., Ezekiel, C.N., Cowx, I.G., Aeron, M., 2007. Towards sustainable exploitation of Nile perch consequential to regulated fisheries in Lake Victoria. Aquat. Ecosyst. Health Manag. 10(4), 449-457.

Moe, C. L., Rheingans, R. D., 2006. Global challenges in water, sanitation and health. J. Wat. Health 4(Suppl. 1), 41-58.

Montgomery, M.R., 2008 The urban transformation of the developing world. Science 319, 761-764.

Moss, B., Kosten, S., Meerhoff, M., Battarbee, R.W., Jeppesen, E., Mazzeo, N., Havens, K., Lacerot, G., Liu, Z., De Meester, L., Paerl, H., Scheffer, M., 2011. Allied attack: climate change and eutrophication. Inland Wat. 1(2), 101-105.

Muggide, R., Hecky, R.E., Hendzel, L.L., Taylor, W.D., 2003. Pelagic nitrogen fixation in Lake Victoria (East Africa). Journal of Great Lakes Research 29, 76-88.

Muggide, R., Hecky, R.E., Ndawula, L., 2005. Chapter Eight - Eutrophication of Lake Victoria, Uganda. In Water Quality and Quantity Synthesis Final report, LVEMP, pp. 131-148.

Musamba, E.B., Ngaga, Y.M., Boon, E.K., Giliba, R.A., 2011. Impact of socio-economic activities around Lake Victoria: Land use and land use changes in Musoma municipality, Tanzania. J. Hum. Ecol. 35, 143-154.

Musungu, P.C., Lalah, J.O., Jondiko, I.O., Ongeri, D.M.K., 2014. The impact of nitrogenous and phosphorus nutrients from selected point sources in Kisumu City on River Kisat and Nyalenda Wigwa Stream before their discharge into Winam Gulf, Lake Victoria. Environ. Earth Sci. 71 (12), 5121-5127.

Muwanga, A., Barifaijo, E., 2006. Impact of industrial activities on heavy metal loading and their physico-chemical effects on wetlands of Lake Victoria basin (Uganda). Afr. J. Sci. Tech. 7, 51-63.

Musinguzi, L., Lugya, J., Rwezawula, P., Kamya, A., Nuwahereza, C., Halafo, J., Kamondo, S., Njaya, F., Aura, C., Shoko, A.P., Osinde, R., Natugonza, V., Ogutu-Ohwayo, R., 2019. The extent of cage aquaculture, adherence to best practices and reflections for sustainable aquaculture on African inland waters. J. Great Lakes Res. 45,1340-1347

Mwavu, E.N., Witkowski, E.T.F., 2008. Land-Use and Cover Changes (1998- 2002) around Budongo Forest Reserve, NW Uganda: Implicationz for Forest and Woodlands Sustainability. Land Degrad. Dev. 19, 606-622.

Nchabeleng, T., Cheng, P., Oberholster, P., Botha, A.-M., Smit, W., Luus-Powell, W., 2014. Microcystin-LR equivalent concentrations in fish tissue during a post bloom Microcystis exposure in Loskop Dam, South Africa. Afr. J. Aquat. Sci. 39, 459-466. 
Ngupula, G.W, Mbonde, A.S.E, Ezekiel, C.N., 2011. Spatial and temporal patterns of phytoplankton abundance and composition in three ecological zones in the Tanzanian waters of Lake Victoria. Afr. J. Aquat. Sci. 36,197-206.

Njiru, J. M., Aura, C. M., \& Okechi, J. K., 2018. Cage fish culture in Lake Victoria: A boon or a disaster in waiting? Fisheries Management and Ecology, 00, 1-9. doi:10.1111/fme.12283

Nyakaana, J.B., Sengendo, H., Lwasa, S., 2007. Population, urban development and the environment in Uganda: the case of Kampala city and its environs. Faculty of Arts, Makerere University, Kampala, Uganda.

Nyanchaga, E.N., Openji, S.O., 2017. Effectiveness of the implementation of the SubCatchment Management Plan - A case study of Awach Kano water resources users association. Int. J. Inn. Stu. Sci. Eng. Tech. 3, 9-15.

O’Neil, J.M., Davis, T.W., Burford, M.A., Gobler, C.J., 2012. The rise of harmful cyanobacteria blooms: The potential roles of eutrophication and climate change. Harmful Algae 14, 313-334.

Ochumba, P.B.O., Kibaara, D.I., 1989. Observations on blue-green algal blooms in the open waters of Lake Victoria, Kenya. Afr. J. Ecol. 27, 23-34.

Odada, E.O., Ochola, W.O., Olago, D.O., 2009. Understanding future ecosystem changes in Lake Victoria basin using participatory local scenarios. Afr. J. Ecol. 47(Suppl. 1), 147153.

Ogutu-Ohwayo, R., 2004. Management of the Nile perch, Lates niloticus fishery in Lake Victoria in light of the changes in its life history characteristics. Afr. J. Ecol. 42, 306314.

Oguttu, H.W., Bugenyi, F.W.B., Leuenberger, H., Wolf, M., Bachofen, R., 2008. Pollution menacing Lake Victoria: Quantification of point sources around Jinja Town, Uganda. Water S.A. 34, 89-98.

Okello, W., Portmann, C., Erhard, M., Gademann, K., Kurmayer, R., 2010a. Occurrence of microcystin-producing cyanobacteria in Ugandan freshwater habitats. Environ. Toxicol. 25(4), 367-380.

Okello, W., Ostermaier, V., Portmann, C., Gademann, K., Kurmayer, R., 2010b. Spatial isolation favours the divergence in microcystin net production by Microcystis in Ugandan freshwater lakes. Wat. Res. 44, 2803-2814

Okello, W., Kurmayer, R., 2011. Seasonal development of cyanobacteria and microcystin production in Ugandan freshwater lakes. Lakes Reserv. Res. Manag. 16, 123-135.

Okeyo-Owuor, J.B, Raburu, P.O., Masese, F.O., Omari, S.N., 2012. Wetlands of Lake Victoria Basin, Kenya: distribution, current status and conservation challenges in Community Based Approach to the Management of Nyando Wetland. Int. J. Novel Res. Hum. Soc. Sci. 3(5), 35-40.

Okungu, J., Opango, P., 2005. Pollution loads into Lake Victoria from the Kenyan catchment. In: C.A. Mallya (Ed.), Knowledge and Experiences gained from Managing the Lake Victoria Ecosystem (pp. 90-108). Dar es Salaam. Regional Secretariat, Lake Victoria Environmental Management Project (LVEMP).

Olokotum, M., 2017. The occurrence and elimination of cyanobacterial toxins in portable water in Uganda: A case study of Gaba III and Walukuba Waterworks. MSc Thesis. 17192. University of Natural Resources and Life Sciences (BOKU), Vienna, Austria.

Opande, G.O., Onyango, J.C., Wagai, S.O., 2004. Lake Victoria: The water hyacinth (Eichhornia crassipes [MART.] SOLMS), its socio-economic effects, control measures and resurgence in the Winam gulf. Limnologica 34(1-2), 105-109.

Opiyo, M.A., Marijani, E., Muendo, P., Odede, R., Leschene, W., Charo-Karisa, H., 2018. Review of aquaculture production and health management practices of farmed fish in 
Kenya. Int. J. Vet. Sci. Med. 6(2), 141-148.

Oyoo, R., 2015. Deteriorating water quality in the Lake Victoria Inner Murchison Bay and its impact on the drinking water supply for Kampala, Uganda. http://wldb.ilec.or.jp/data/ilec/WLC13_Papers/others/3.pdf

Padmavathi, P., Veeraiah, K., 2009. Studies on the influence of Microcystis aeruginosa on the ecology and fish production of carp culture ponds. J. Biotechnol 8(9), 1911-1918.

Paerl, H.W., Gardner, W.S., Havens K.E., Joyner A.R., McCarthy M.J., Newell S.E., Qin, B., Scott, J.T., 2016. Mitigating cyanobacterial harmful algal blooms in aquatic ecosystems impacted by climate change and anthropogenic nutrients. Harmful Algae 54, 213-222.

Place, F., Otsuka, K., 2002. Land tenure systems and their impacts on agricultural investments and productivity in Uganda. J. Dev. Studies 38(6), 105-128.

Poste, A.E., Hecky, R.E., Guildford S.J., 2011. Evaluating Microcystin Exposure Risk through Fish Consumption. Env. Sci. Technol. 45, 5806-5811.

Poste, A.E., Hecky, R.E., Guildford, S.J., 2013. Phosphorus enrichment and carbon depletion contribute to high Microcystis biomass and microcystin concentrations in Ugandan lakes. Limnol. Oceanogr. 58(3), 1075-1088.

Raburu, P.O., Okeyo-Owuor, J.B., Kwena, F., 2012. Community Based Approach to the Management of Nyando Wetland, Lake Victoria Basin, Kenya. KDC - VIRED UNDP. Nairobi, Kenya.

Roegner, A., Sitoki, L., Weirich, C., Corman, J., Owage, D., Umami, M., Odada, E., Miruka, J., Ogari, Z., Smith, W., Rejmankova, E., Miller, T.R., 2020. Harmful algal blooms threaten the health of peri-urban fisher communities: A case study in Kisumu Bay, Lake Victoria, Kenya. Expos Health, Early access Feb 2020 (https://doiorg.inee.bib.cnrs.fr/10.1007/s12403-019-00342-8)

Rumisha, C., Nehemia, A., 2013. Feeding selectivity of wild and pond-cultured Nile tilapia Oreochromis niloticus in the lake Victoria basin in Mara, Tanzania. Afr. J. Aquat. Sci. $38,55-60$.

Schuijt, K., 2002. Land and water use of wetlands in Africa: Economic values of African wetlands. doi.org/10.1016/j.molcel.2012.05.044.

Sekadende, B.C., Lyimo, T.J., Kurmayer, R., 2005. Microcystin production by cyanobacteria in the Mwanza Gulf (Lake Victoria, Tanzania). Hydrobiologia 543(1), 299-304.

Semyalo, R., Rohrlack, T., Naggawa, C., Nyakairu, G.W., 2010. Microcystin concentrations in Nile tilapia (Oreochromis niloticus) caught from murchison Bay, Lake Victoria and Lake Mburo: Uganda. Hydrobiologia 628, 235-244.

Semyalo, R., Rohrlack, T., Kayiira, D., Kizito, Y.S., Byarujali, S., Nyakairu, G., Larsson, P., 2011. On the diet of Nile tilapia in two eutrophic tropical lakes containing toxin producing cyanobacteria. Limnologica 41, 30-36.

Shayo, S.D., Lugomela, C., Machiwa, J.F., 2011. Influence of land use pattern on some limnological characteristics in the south-eastern part of Lake Victorian, Tanzania. Aquat. Ecosyst. Health Manag. 14, 246-251.

Silsbe, G.M., Hecky, R.E., Guildford, S.J., 2006. Variability of chlorophyll $a$ and photosynthetic parameters in a nutrient-saturated tropical great lake. Limnol. Oceanogr. 51(5), 2052-2063.

Simiyu, B.M., Oduor, S.O., Rohrlack, T., Sitoki, L., Kurmayer, R., 2018. Microcystin content in phytoplankton and in small fish from eutrophic Nyanza Gulf, lake Victoria, Kenya. Toxins 10(7), 1-19.

Simonit, S., Perrings, C., 2011. Sustainability and the value of the 'regulating' services: Wetlands and water quality in Lake Victoria. Ecol. Econom. 70(6), 1189-1199.

Sitoki, L., Kurmayer, R., Rott, E., 2012. Spatial variation of phytoplankton composition, 
1089

1090

1091

1092

1093

1094

1095

1096

1097

1098

1099

1100

1101

1102

1103

1104

1105

1106

1107

1108

1109

1110

1111

1112

1113

1114

1115

1116

1117

1118

1119

1120

1121

1122

1123

1124

1125

1126

1127

1128

1129

1130

1131

1132

1133

1134

1135

1136

1137

1138

biovolume, and resulting microcystin concentrations in the Nyanza Gulf (Lake Victoria, Kenya). Hydrobiologia 691, 109-122.

Spoof, L., Catherine, A., 2017. Appendix 3 - Tables of Microcystins and Nodularins.. In Handbook of Cyanobacterial Monitroing and Cyanotoxin Analysis. Meriluoto J., Spoof L. and Codd G.A. Eds. Hohn Wiley \& Sons, Ltd, 526-537.

Ssebiyonga, N., Erga, S.R., Hamre, B., Stamnes, J.J., Frette, Ø., 2013. Light conditions and photosynthetic efficiency of phytoplankton in Murchison Bay, Lake Victoria, Uganda. Limnologica 43(3), 185-193.

Stager, J.C., Hecky, R.E., Grzesik, D., Cumming, B.F., Kling, H., 2009. Diatom evidence for the timing and causes of eutrophication in Lake Victoria, East Africa. Hydrobiologia 636, 463-478.

Svircev, Z., Lalic, D., Bojadzija Savic, G., Tokodi, N., Drobac Backovic, D., Chen, L., Meriluoto, J., Codd, G.A., 2019. Global geographical and historical overview of cyanotoxin distribution and cyanobacterial poisonings Arch. Toxicol. 93, 2429-2481.

Talling, J.F., 1966. The annual cycle of stratification and phytoplankton growth in Lake Victoria. Int. Revue ges. Hydrobiol. 51, 545-621.

Talling, J.F., 1987. The phytoplankton of Lake Victoria (East Africa). Arch. Hydrobiol. Beih. Ergebn. Limnol. 25, 229-256.

Tamatamah, R.A., Hecky, R.E., Duthie, H.C., 2005. The atmospheric deposition of phosphorus in Lake Victoria (East Africa). Biogeochem. 73, 325-344.

Taranu, Z.E., Gregory-Eaves, I., Leavitt, P.R., Bunting, L., Buchaca, T., Catalan J., Domaison, I., Guilizzoni, P., Lami, A., McGowan, S., Moorhouse, H., Morabito, G., Pick, F.R., Stevenson, M.A., Thompson, P.L., Vinebrooke, R.D., 2015. Acceleration of cyanobacterial dominance in north temperate-subarctic lakes during the Anthropocene. Ecol. Lett. 18(4), 375-384.

Tariku, TB., Gan, T.Y., 2018. Regional climate change impact on extreme precipitation and temperature of the Nile river basin. Clim. Dyna. 51, 3487-3506.

Teferi, Y., Admassu, D., Mengistou, S., 2000. The food and feeding habit of Oreochromis niloticus L. (Pisces: Cichlidae) in Lake Chamo, Ethiopia. SINET: Ethiop. J. Sci. 23(1), $1-12$.

Thiery, W., Davin, E.L., Seneviratne, S.I., Bedka, K., Lhermitte, S., van Lipzig, N.P.M., 2016. Hazardous thunderstorm intensification over Lake Victoria. Nature Comm. 7 , 12786.

Torres, G.S., Silva, L.H., Rangel, L.M., Attayde, J.L., Huszar, V. L., 2016. Cyanobacteria are controlled by omnivorous filter-feeding fish (Nile tilapia) in a tropical eutrophic reservoir. Hydrobiologia, 765, 115-129.

Turker, H., Eversole, A. G., Brune, D. E., 2003. Filtration of green algae and cyanobacteria by Nile tilapia, Oreochromis niloticus, in the Partitioned Aquaculture System. Aquaculture 215, 93-101.

United Nations Environment Program-UNEP, 2006. UNEP 2006 annual report. https://www.unenvironment.org/resources/annual-report/unep-2006-annual-report.

United Nations Environment Program-UNEP, 2008. Africa: Atlas of our changing environment. Malta: Progress Press.

United Nations, Department of Economic and Social Affairs, Population Division, 2019. World Urbanization Prospects 2018: Highlights (ST/ESA/SER.A/421).

Verschuren, D., Johnson, T.C., Kling, H.J., Edgington, D.N., Leavitt, P.R., Brown, E.T., Talbot, M.R., Hecky, R.E., 2002. History and timing of human impact on Lake Victoria, East Africa. Proc.. Biol. Sci. Royal Soc. 269(1488), 289-294.

Vuai, S.A.H., Ibembe, J.D., Mungai, N.W., 2013. Influence of land use activities on spatial and temporal variations of nutrient deposition in Mwanza region: Implication to the 
atmospheric loading to the Lake Victoria. Atmosph. Clim. Sci. 3, 224-234.

Wacker, C., Okello, W., Gitau, M.K., Wolf, M., 2016. Participatory wetland management at the shoreline of Lake Victoria in Jinja, Uganda. Kampala: Fountain Publishers.

Waiswa, D., Stezrn, M.J., Prisley, S.P., 2015. Drivers of deforestation in the Lake Victoria crescent, Uganda. J. Sustain. Forest. 34, 259-275.

Wanda, F.M., Namukose, M., Matuha, M., 2015. Water hyacinth hotspots in the Uganda water of Lake Victoria in 1993-2012: implications for management. Afr. J. Aqu. Sci. 40, 101-106.

Wang, H., Wang, T., Zhang, B., Li, F., Toure, B., Omosa, I.B., Chiramba, T., Abdel-Monem, M., Pradhan, M., 2014. Water and wastewater treatment in Africa - Current practices and challenges. Clean (Weinh) 42, 1029-1035.

Watson, S.B., Miller, C., Arhonditsis, G., Boyer, G.L., Carmichael, W., Charlton, M.N., Confesor, R., Depew, D.C., Höök, T.O., Ludsin, S.A., Matisoff, G., McElmurry, S.P., Murray, M.W., Richards, R.P., Rao, Y.R., Steffen, M.M., Wilhelm, S.W., 2016. The re-eutrophication of Lake Erie: Harmful algal blooms and hypoxia. Harmful Algae 56, 44-66.

Witte, F., Silsbe, G.M., Hecky, R.E., Goudswaard, P.C., Guildford, S.J., Kishe-Machumu, M.A., Wanink, J.H., 2012. Did the loss of phytoplanktivorous fish contribute to algal blooms in the Mwanza Gulf of Lake Victoria? Hydrobiologia 679, 283-296.

World Population Prospect, 2017. Unitied Nations - DESA/Population Division. https://population.un.org/wpp/

Zakaria, M., Zienab, A., Bakr, A., 2019. Assessment of phytoplankton species in gut and feces of cultured tilapia fish in Egyptian fishponds - Implications for feeding and bloom control. Acta Limnol. Brasil., 31, e27.

Zhang, S., Liu, J., Wei, S., Zhang, K., 2016. Impact of aquaculture on eutrophication in Changshou Reservoir. Chin. J. Geochem. 25(1), 90-96. 
1170 Supplemental Table 1. Dissolved nutrient and chlorophyll-a concentrations in the Lake 1171 Victoria

1172

1173 Supplemental Figure 1. Chlorophyll-a and microcystin concentrations in the main lake and

1174 in the bays and gulfs of the Lake Victoria

1175

1176 Supplemental Figure 2. Population size dynamics in the five countries of the watershed of

1177 Lake Victoria (data from the "World Population Prospects, The 2017 Revision", United

1178 Nations; https://population.un.org/wpp/Download/Standard/Population/)

1179

1180 Supplemental Figure 3. Geographical distribution of the human population densities in the 1181 Lake Victoria watershed. 